\title{
A NUMERICAL STUDY FOR PREDICTION OF FORMING LOAD AND EXPERIMENTAL VERIFICATION OF BIMETALLIC DISC UPSETTING
}

\author{
Önder Ayer
}

Original scientific paper Forming of disc samples composed from aluminium and copper in performed study was examined with upsetting procedure. An approach for prediction deformation load of upsetting processes is developed. This study combines the finite element method model, neural network model and upper bound method to simulate and predict the deformation load in upsetting of bimetallic materials. The Finite Element Method (FEM) results were obtained from DEFORM-3D software and they were compared and validated with experiments by taking forming load into consideration. Also, Artificial Neural Network (ANN) model was used to analyze and predict the forming load for different process parameters. The Upper Bound (UB) model was also proposed to estimate the forming load and the results were compared with experiments. It was understood that calculated results were in concordance with experimental results in upsetting of bimetallic hollow discs. Thus, proposed ANN, FEM and UB models provide a valuable insight into the parameters affecting forming load and can be named as useful tools to predict the forming load without the need of any experiments.

Keywords: artificial neural network (ANN); bimetallic materials; DEFORM-3D; finite element method (FEM); load analysis; upper bound method (UB); upsetting

\section{Numerička analiza za predviđanje nastalog opterećenja i eksperimentalna provjera sabijanja bimetalnog diska}

Izvorni znanstveni članak

U ovom je istraživanju postupkom sabijanja ispitivano nastajanje pločastih uzoraka sastavljenih od aluminija i bakra. Razvijen je pristup za predviđanje opterećenja koje dovodi do deformacije u postupku sabijanja. U radu se kombinira model metode konačnih elemenata, neuronske mreže i metode gornje granice (upper bound) u svrhu simuliranja i predviđanja opterećenja koje dovodi do deformacije u postupku sabijanja bimetalnih materijala. Rezultati metode konačnih elemenata (FEM) dobiveni su softverom DEFORM-3D te su uspoređeni i provjereni na eksperimentima uzimajući u obzir stvoreno opterećenje. Primijenio se i model Umjetne Neuronske Mreže (Artificial Neural Network - ANN) za analizu i predviđanje nastalog opterećenja kod različitih parametara postupka. Za procjenu nastalog opterećenja predložen je i Upper Bound (UB) model, a rezultati su eksperimentalno uspoređivani. Ustanovilo se da su dobiveni rezultati u skladu s eksperimentalnima u sabijanju bimetalnih šupljih diskova. Prema tome, predloženi ANN, FEM i UB modeli pružaju dragocjen uvid u parametre koji utječu na stvaranje opterećenja i može ih se smatrati korisnim alatima za predviđanje stvaranja opterećenja bez potrebe bilo kakvih eksperimenata.

Ključne riječi: analiza opterećenja; bimetalni materijali; DEFORM-3D; metoda gornje granice (UB); metoda konačnih elemenata (FEM); sabijanje; umjetna neuronska mreža (ANN)

\section{Introduction}

Bimetallic materials are a type of composite materials which act like a single material just like different alloys of the same material or a new material which is manufactured by bringing two types of different materials together physically. For a long time, bimetallic materials have been used in daily life in several forms such as thermometer, thermo element (thermocouple) and coins. Bimetallic materials have different features than materials formed by using superior features of two different materials which they are composed of. They are preferred for their weight disposition, corrosion resistance, fatigue strength and low costs. For example, a bimetallic material which was obtained by using aluminium in inner part and steel in outer part shall be lighter than whole steel material and more durable than whole aluminium material. Nowadays bimetallic materials started to take part in several areas as a perfect alternative material. Notably, conducting wire, steam traps, engine bedding plates, rivet stock industry, sensors, thermometers; thermostats are various areas of usage. Manufacturing methods of bimetallic materials are mostly coating, close fitting and casting. Even though obtaining bimetal materials by upsetting method was found with coin production and dates back to old times, recently it is considered as a little bit important method. Nevertheless there are not many studies on forming of bimetallic materials.
Chitkara and Aleem [1] published a study about axisymmetric extrusion of bimetallic tubes and compared the obtained experimental results with analyses. Haghighat and Asgari [2] proposed a new velocity field for extrusion of bi-metallic materials and obtained numerical results. Kazanowski et al. [3] studied the effect of the billet geometry on the product geometry for bimaterial rod extrusion. They confirmed the relation between initial geometries and the quality of the final product. They found that the optimal core material height was about $15-20 \%$ shorter than the billet's sleeve material height for the analyzed process conditions. Haghighat and Mahdavi [4] investigated the bimetal tube extrusion process through rotating conical dies both analytically and numerically. They offered a kinematically admissible velocity field to calculate the internal power and the power dissipated on frictional and velocity discontinuity surfaces and they found that the extrusion pressure decreased by about $20 \%$ by the die rotation. Wifi et al. [5] simulated upsetting of discs and rings using an updated Lagrangian, elasto-plastic large strain finite element code. Plančak et al. [6] studied forming two different geometries in closed die by using two different materials as a bimetallic material and also analysed the forming load, material flow and filling of joint section. Kačmarčik et al. [7] investigated backward extrusion of bimetallic materials both experimentally and numerically and they expanded their study on gear like profiles by using FEM method. Eivani and Karimi Taheri [8] proposed a new method for producing bimetallic rods by ECAE process. 
Barata Marques and Martins [9] simulated the joint of a bi-metal coin using rigid-plastic formulation. Different joint profiles have been analyzed and presented the theoretical predictions of the joining load, the velocity field, the strain field and the deformed grid patterns in their study. Plančak et al. [10] investigated compression of bimetallic components by using $\mathrm{C} 15 \mathrm{E}$ and $\mathrm{C} 45 \mathrm{E}$ steel for inner and our materials for experimental study and used slab method for analytical approach. Essa et al. [11] also expanded their research using the same materials $\mathrm{C} 15 \mathrm{E}$ as softer material for core and stronger material $\mathrm{C} 45 \mathrm{E}$ as sleeve for upsetting experiments and they investigated interface of these two components using cylindrical samples with different H/D ratios. They analyzed the experimental results with FEM results. Also Çetintav [12] investigated the behaviour and mechanical properties of cylindrical bimetallic materials that were produced as a single part using two different materials during cold upsetting process with the combination of pure copper, brass and 1020 steel.

Ko and Kim [13] proposed a new technique for the design consideration of workability of metals. They predicted ductile fracture combining the finite element simulation with ductile fracture criterion. The artificial neural network (ANN) using Taguchi method was implemented in their study. The combinations of design parameters were selected by a specific combination of experiments. Their study showed that the proposed method gives deeper foresight to design multi-stage processes and also establishes an analytical basis for preform design for various metal forming processes. Gudur and Dixit [14] used Artificial Neural Network model to assist FEM model for the modelling of cold flat rolling process. This approach reduced the computational time. Azari et al. [15] studied the application of FEM and ANN methods to predict the forming load during the radial forging process with the initial conditions like feed rate, die inlet angle, the initial billet temperature and reduction in cross-section. Sanjari et al. [16] optimized the radial force and strain inhomogeneity in radial forging process by applying the ANN and the Taguchi method. They concluded in their research that an ANN model using orthogonal arrays as training data gives more accurate performance than the Taguchi method for prediction. Djavanroodi et al. [17] investigated the possibility of using combined method with artificial neural networks and finite element method for the fineblanking process analysis. It was shown by the authors' study that the combination of FEM and ANN method reduced the simulation time and was a practical view for optimal process parameters in fine-blanking and also for satisfactory prediction results. Chun et al. [18] made predictions for the flow stress, roll torque and roll force obtained from the hot compression and rolling of aluminium alloys by using an ANN model with a backpropagation learning algorithm. Authors showed that neural network models provide fast, accurate and consistent results. Kim and Kim [19] proposed a new technique for neural network method to determine the initial billet and to design the die geometry. The process conditions are designed for axisymmetric hot forging with the full-filling of the die cavity by using the FEM simulations. Authors used the FEM data to obtain the aspect ratios which full-filled the die cavity. In another study, Kim et al. [20] determined the initial billet geometry for the forged products by a function approximation in neural networks. A three-layer neural network was used and the back-propagation algorithm was chosen for training data. Authors applied the neural networks for the optimal initial billet size in cold forging and for an axisymmetric rib-web product in hot forging. Mohammadi Majd et al. [21] used a four-layer back propagation network to best fit for a barrelling curve which is defined as a nonlinear engineering problem. The output data was the coefficient of a function of barrelling curves. Finite element simulations were used for generating barrelling curves for the training data of the neural network model. Poshal and Ganesan [22] carried out cold upsetting experiments on sintered aluminium preforms. They investigated the formability of aluminium sintered specimens by using Artificial Neural Network (ANN). ANN was established on a radial basis neural network algorithm. Their regression analysis showed a good agreement between estimated and experimental results with small error values. Therefore, this approach could be a helpful method to give foresight for preventing from the surface defects and reducing the cost of predesign stage.

The researchers tried a number of different mathematical studies on metal forming processes and Upper bound method is one of the most used mathematical methods. Yang et al. [23] performed upper bound method to estimate the forming load during the upsetting of cylindrical samples. Altınbalık and Çan [24] investigated barrelling profile of upset billet and tried to evaluate the forming load by using modified upper bound solution which included dimensionless optimized parameters. Hsu presented a dimensionless optimization parameter to obtain the forming load of a precision gear forging process. Hsu [25] analyzed a number of process parameters and compared with those of other researcher's analytical and experimental studies. Martin et al. [26] proposed a new perspective to calculate the neutral plane for ring compression test. They selected Triangular Rigid Blocks model for upper bound solution of the process. Chandra and Srivastava [27] investigated the axisymmetric upsetting by using boundary element analysis to evaluate the ring compression test results. Yeh and $\mathrm{Wu}$ [28] studied the upsetting of rings. They used a variational upper-bound (VUB) model which was neglected in the traditional upper bound method to predict the barrelling profile of the upset ring and also the total forming energy rate. They compared the results with FEM results and showed that this can be applicable to upsetting of rings. Moncada et al. [29] applied the upper bound theorem with a triangular rigid zones model which is generally used for plane strain and symmetrical geometric sections for non-symmetric samples.

In the presented study upsetting of bimetallic hollow discs was investigated by using commercially pure aluminium as sleeve material and electrolytic copper as core material. The forming load was selected as main output parameters for the analyses. The FEM model was built for disc upsetting process to simulate the forming load and the results were compared with experiments. Moreover, ANN and UB models were also established to predict the forming load for different process parameters. 


\section{Experimental method}

Bimetallic material was built with commercially pure aluminium (Al 1070) and electrolytic copper. Al 1070 aluminium was selected as sleeve material in view of its higher mechanical properties comparing to core material which was electrolytic copper. Stress-strain curves of the materials were given in Eq. (1) and Eq. (2).

$$
\begin{aligned}
& \sigma_{\mathrm{Al}}=144 \cdot \varepsilon^{0.162}, \\
& \sigma_{\mathrm{Cu}}=319 \cdot \varepsilon^{0.583} .
\end{aligned}
$$

The dimensions of the bimetallic samples can be seen in Fig. 1 were carried out by Universal test machine which has $600 \mathrm{kN}$ capacity and 0.4 Class accurate load cell. The test machine is controlled by software which collects data from the load cell and performs it for obtaining load-displacement curves. The die design and test machine is given in Fig. 2. Billets were compressed using flat faced platens made from AISI H13 hot work tool steel, hardened to $58 \mathrm{HRC}$. Dies were oil quenched and tempered at $550{ }^{\circ} \mathrm{C}$ and flat faces of the dies were ground after heat treatment by a magnetic plate grinding machine in order to obtain the final dimensions and surface quality of the dies. The surfaces of the platens were cleaned with acetone to ensure the same friction conditions for all specimens for each test. The cylindrical specimens were centered on the lower die and upsetting load was applied for different deformation ratio values. Height in reductions for $10 \%, 20 \%, 30 \%$ ratios was calculated and selected for the experimental study.

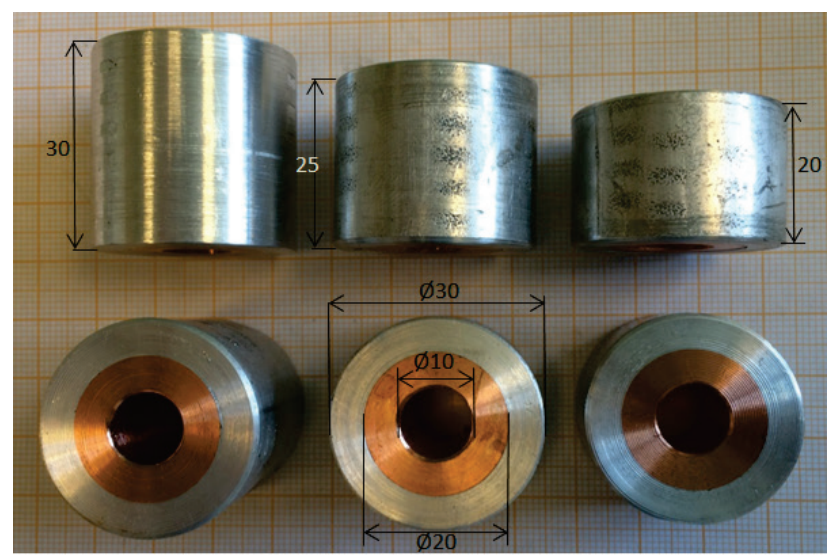

Figure 1 Photographical views of workpieces and dimensions

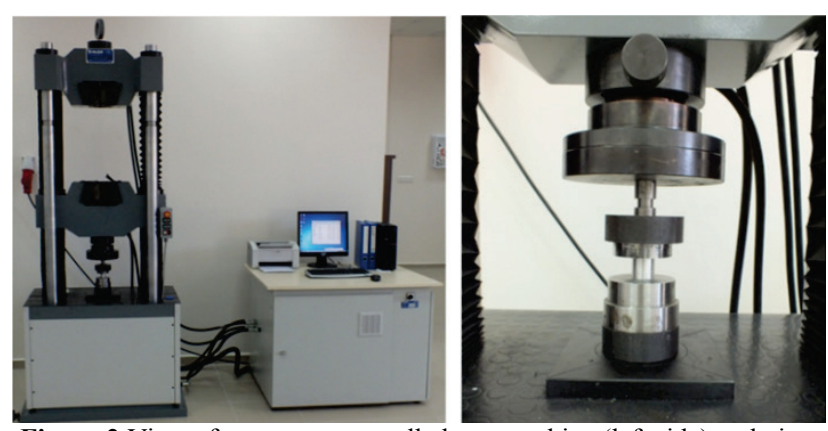

Figure 2 View of computer controlled test machine (left side) and view of sample and die design (right side)

\section{Finite Element Method (FEM)}

Finite Element Method has been one of the most useful mathematical approaches for solution of the complicated engineering problems. DEFORM is one of FEM based software specialized for metal forming processes and DEFORM-3D v10.2 was used in this study to simulate and analyze the process. All the components' geometry given in Fig. 3 was modeled by commercial CAD software and then exported to DEFORM-3D software. DEFORM-3D software was chosen for its realistic simulation potential of upsetting process suitably. In the presented study, mesh distribution in the FEM method has a great importance not only for sensitive FEM results but also to save calculation time and data storage space. Because of this reason, optimum mesh distribution was applied to the model. In order to simulate the experiments more realistic, environment temperature was selected as room temperature, punch velocity was defined as $5 \mathrm{~mm} / \mathrm{sec}$. The friction type considered as shear and the friction factor $(m)$ between the workpiece and the dies was calculated as constant and it was defined as $m=0.4$ for all Aluminum/Die and Copper/Die contact surfaces obtained from the ring compression test. Friction is neglected at the aluminum and copper material interface. The iteration method selected as direct method and the type of the simulation was Lagrangian Incremental. The dies were set as rigid bodies and all deformations of the dies were neglected. H13 steel was selected as a die material. CDA 110 was selected for core material and ALUMINIUM 1070A was for sleeve material in the FEM simulations from the software library. Both workpiece materials were modeled using approximately 35000 elements for accurate FEM results. The convergence error limit for velocity and load was 0.005 and 0.05 respectively. The global remeshing was chosen and the type of interference depth was selected as relative and its value was considered as 0.7 . The Conjugate-Gradient solver was used to solve the problem because of its capability for complex geometries.
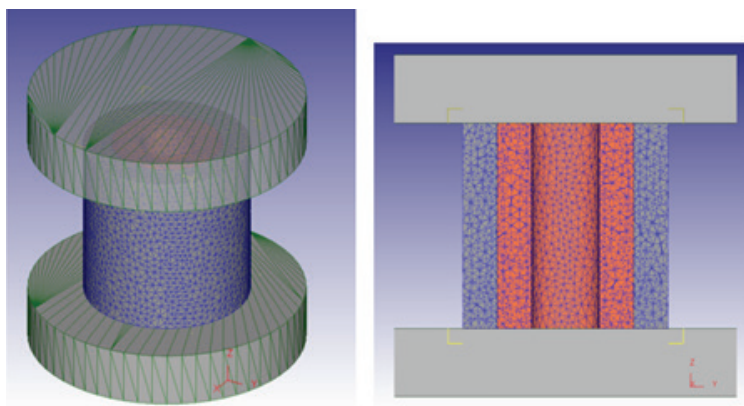

Figure 3 View of FEM model of die assembly and bimetallic material

\section{Artificial Neural Network Method (ANN)}

Trial is an expensive method because of demanding lots of experiments to build any practical model and addition to this, choosing FEM techniques has another disadvantage like having mathematical limitations. Furthermore FEM method needs much CPU time for detailed analysis of the problems. A small change for a single process parameter requires an updated simulation model and analysis to calculate the effect on forming 
load. However, ANN is a parallel distributed processing system; hence a trainable nonlinear system needs less simulation time. The main idea behind a neural network method is very close to the human brain activities. There is an interconnected structure familiar to brain cells of human neural networks. There are large numbers of simple processors named neurons arranged in different layers in the neural network. Once the architecture of network is defined, proposed ANN method is capable of learning from the sample data set named training set, so weights are calculated accordingly. It is also important to evaluate the performance of the built ANN model for the later stages of the ANN prediction. This is succeeded by separating the data into two sets named as the training and validation set. In other words, target values are necessary to train and test the built ANN network. The training data are calculated values executed by using the selected results from experiments for different parameters. ANN model is trained by using Levenberg-Marquardt algorithm because of its converging performance and giving less absolute error among the several algorithms available. The flowchart of the proposed ANN model is given in Fig. 4.

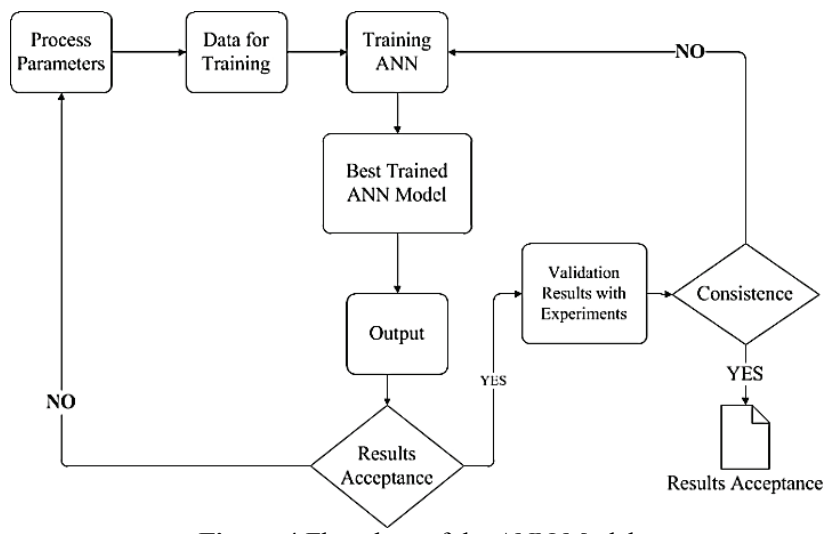

Figure 4 Flowchart of the ANN Model

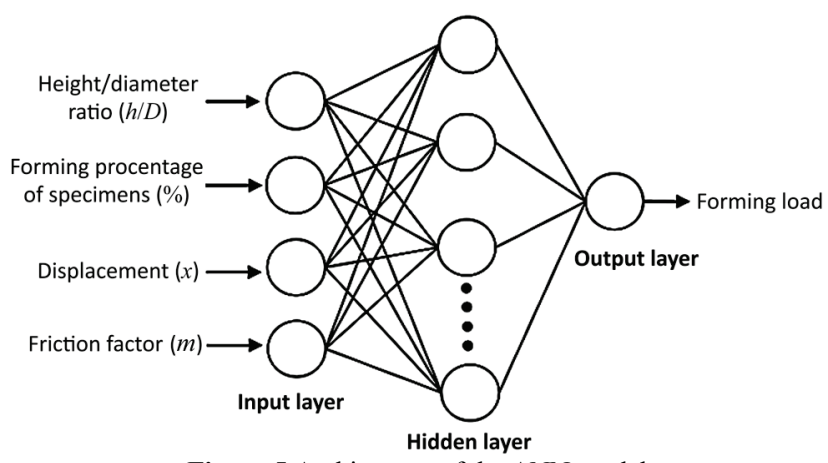

Figure 5 Architecture of the ANN model

The three imperative parameters named height to diameter ratio, forming percentage of specimens, and displacement of the punch were used as initial parameters where the output parameter was forming load. The displacement was used as an input neuron to determine forming load at certain ram travel path at various experimental process variations. The architecture of the ANN model is given in Fig. 5. A transfer function is necessary to translate the input signals to output signals because of having a great importance for the accuracy of the ANN results and its selection depends mostly on experience. A TanhAxon function was selected as the main transfer function of the model. The proposed ANN model for extrusion load of different parameters was chosen as the feed-forward neural networks consisting of multilayer perceptions trained back-propagation algorithms. The back-propagation learning algorithm was also used in a feed-forward - single hidden layer network.

\section{Upper Bound Method (UB)}

The upper bound theorem is a theoretical method to estimate the required maximum energy to deform material plastically into the desired shape. A number of studies have been performed to obtain appropriate results for both metal forming studies and simulations by using upper bound for the last three decades. In this study, it was aimed to estimate the maximum forming load for bimetallic upsetting process by using UB method but some assumptions had to be made for this aim. The billet was assumed as isotropic and plastically deformable obeying von-Mises flow rule. The dies were defined as rigid bodies and all of the elastic deformation was neglected. The friction factor between die and workpiece material interfaces was assumed as constant. The upper die movement was fixed as a constant value which was defined for this study as $5 \mathrm{~mm} / \mathrm{s}$. The suitable velocity field which satisfies the incompressibility and continuity theorem should be defined for obtaining the total energy value and eventually forming load. The upper bound method includes precisely the effect of both internal forming energy induced by the distortion from the plastic flow and the existing external friction of the interfaces between tool and workpiece. The friction is generally adhesion friction which is the result of the applied highorder stresses and denoted by shear factor $\mathrm{m}$. The general total forming energy formulae was given as follows:

$$
\begin{aligned}
& J^{*}= \\
& =\frac{2}{\sqrt{3}} \sigma_{0} \int_{V} \sqrt{\frac{1}{2} \dot{\varepsilon}_{i j} \dot{\varepsilon}_{i j}} \mathrm{~d} V+\int_{\tau_{S}} \tau|\Delta v| \mathrm{d} s+\frac{m}{\sqrt{3}} \int_{S} \sigma_{0} \Delta V \mathrm{~d} s .
\end{aligned}
$$

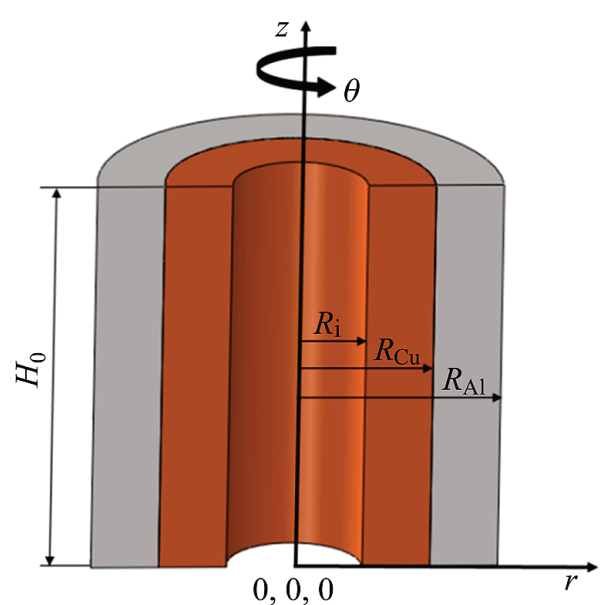

Figure 6 Cylindrical co-ordinate system of the UB model

The initial necessary power over volume $(V)$ is represented with the first right hand term and second term expresses the shear losses and finally third term represents the frictional losses on the tool-workpiece interfaces. $\sigma_{0}$ gives the flow stress of the material and $\varepsilon_{i j}$ is the strain 
rate tensor, $m$ is the constant friction factor occurring from the applied stress between the tool and workpiece, $|\Delta V|$ is the velocity discontinuity over the shear surfaces. $J^{*}$ is the required total energy amount for the given process parameters. In this study, the workpiece flows freely so the shear losses could be neglected.

The velocity field which satisfies the boundary conditions was defined in the cylindrical coordinates as below:

$$
\begin{aligned}
& V_{r}=\left(\frac{V_{0} r}{2 h}\right) \cdot\left\{1+Q \cdot\left[\left(\frac{2 z}{h}\right)-1\right]\right\}, \\
& V_{z}=-\left(\frac{V_{0}}{4 Q}\right) \cdot\left[Q \cdot\left(\frac{2 z}{h}-1\right)+1\right]^{2}, \\
& V_{\theta}=0 .
\end{aligned}
$$

$V_{r}, V_{\theta}, V_{z}$ are the radial, circumferential and axial velocity components of the cylindrical coordinate system, respectively. $V_{\theta}$ is assumed as zero because of the process material flows freely in angular axis without any discontinuity. $Q$ is the pseudo-independent optimal parameter for non-uniform axisymmetric velocity field based on the frictional conditions related with experiments. The upper bound approach results were optimized with reference to $Q$ parameter. It is possible to calculate the strain rates from the above velocity fields:

$$
\begin{aligned}
& \dot{\varepsilon}_{r r}(r, \theta, z)=\frac{\partial V_{r}}{\partial r}=\left(\frac{V_{0}}{2 h}\right) \cdot\left\{Q \cdot\left[\left(\frac{2 z}{h}\right)-1\right]+1\right\} \\
& \dot{\varepsilon}_{\theta \theta}(r, \theta, z)=\frac{1}{2} \cdot \frac{\partial V_{\theta}}{\partial \theta}+\frac{V_{r}}{r}=\left(\frac{V_{0}}{2 h}\right) \cdot\left\{Q \cdot\left[\left(\frac{2 z}{h}\right)-1\right]+1\right\}, \\
& \dot{\varepsilon}_{z z}(r, \theta, z)=\frac{\partial V_{z}}{\partial z}=\left(\frac{V_{0}}{h}\right) \cdot\left\{Q \cdot\left[\left(\frac{2 z}{h}\right)-1\right]+1\right\} \\
& \dot{\varepsilon}_{r z}(r, \theta, z)=\frac{1}{2} \cdot\left(\frac{\partial V_{r}}{\partial z}+\frac{\partial V_{z}}{\partial r}\right)=\frac{Q \cdot V_{0} \cdot r}{2 h^{2}} \\
& \dot{\varepsilon}_{\theta z}(r, \theta, z)=\dot{\varepsilon}_{r \theta}(r, \theta, z)=0
\end{aligned}
$$

The obtained strain rates should provide the volume constancy and it was expressed in Eq. (12):

$$
\dot{\varepsilon}_{r r}+\dot{\varepsilon}_{z z}+\dot{\varepsilon}_{\theta \theta}=0
$$

Effective strain should be calculated to obtain initial deformation energy.

$$
\begin{aligned}
\varepsilon_{\text {eff }} & =\frac{2}{\sqrt{3}} \cdot \sqrt{\frac{1}{2}\left(\dot{\varepsilon}_{r r}+\dot{\varepsilon}_{z z}+\dot{\varepsilon}_{\theta \theta}\right)^{2}+\dot{\varepsilon}_{\theta z}^{2}+\dot{\varepsilon}_{r \theta}^{2}+\dot{\varepsilon}_{r z}^{2}}= \\
& =\frac{1}{3} \cdot \sqrt{\frac{3 Q^{2} \cdot V_{0}^{2} \cdot r^{2}}{h^{4}}} .
\end{aligned}
$$

Initial deformation energy can be calculated by taking account that there are two materials and the friction factor was accepted as zero between copper and aluminum interfaces.

$$
\begin{aligned}
W_{\mathrm{i}} & =\int_{R_{\mathrm{i}}}^{R_{\mathrm{Cu}}} \sigma_{\mathrm{Cu}} \cdot \varepsilon_{\mathrm{eff}}\left(2 \pi \cdot r \cdot\left(H_{0}-h\right)\right) \mathrm{d} r+ \\
& +\int_{R_{\mathrm{Cu}}}^{R_{\mathrm{Al}}} \sigma_{\mathrm{Al}} \cdot \varepsilon_{\mathrm{eff}}\left(2 \pi \cdot r \cdot\left(H_{0}-h\right)\right) \mathrm{d} r .
\end{aligned}
$$

$\sigma_{\mathrm{Cu}}$ and $\sigma_{\mathrm{Al}}$ are the flow stress of copper and aluminum respectively. The energy required for frictional losses was given in Eq. 15.

$$
\begin{aligned}
W_{\mathrm{f}} & =2 \int_{R_{\mathrm{i}}}^{R_{\mathrm{Cu}}}\left(\frac{m \cdot \sigma_{\mathrm{Cu}}}{\sqrt{3}}\right) \cdot(\Delta V) \cdot(2 \pi \cdot r) \mathrm{d} r+ \\
& +2 \int_{R_{\mathrm{Cu}}}^{R_{\mathrm{Al}}}\left(\frac{m \cdot \sigma_{\mathrm{Al}}}{\sqrt{3}}\right) \cdot(\Delta V) \cdot(2 \pi \cdot r) \mathrm{d} r .
\end{aligned}
$$

Total energy requirement can be calculated by the sum of initial deformation and frictional losses.

$J^{*}=W_{\mathrm{i}}+W_{\mathrm{f}}$

Finally, forming load can be calculated after the total energy amount was calculated as seen in Eq. (17) where $V_{0}$ is the upper die velocity;

$F=\frac{J^{*}}{V_{0}}$.

\section{Results and discussions}

In this study, influence of forming load for different parameters on bimetallic disc upsetting was investigated. FEM model was constructed by DEFORM-3D software, ANN and UB models were built and all of the simulation results were compared with experimental results. Moreover, ANN and UB models were studied to simulate the upsetting process for various parameters.

\subsection{FEM Analysis}

In this section, the experimental and FEM results of bimetallic upsetting were compared by using the loaddisplacement diagrams.

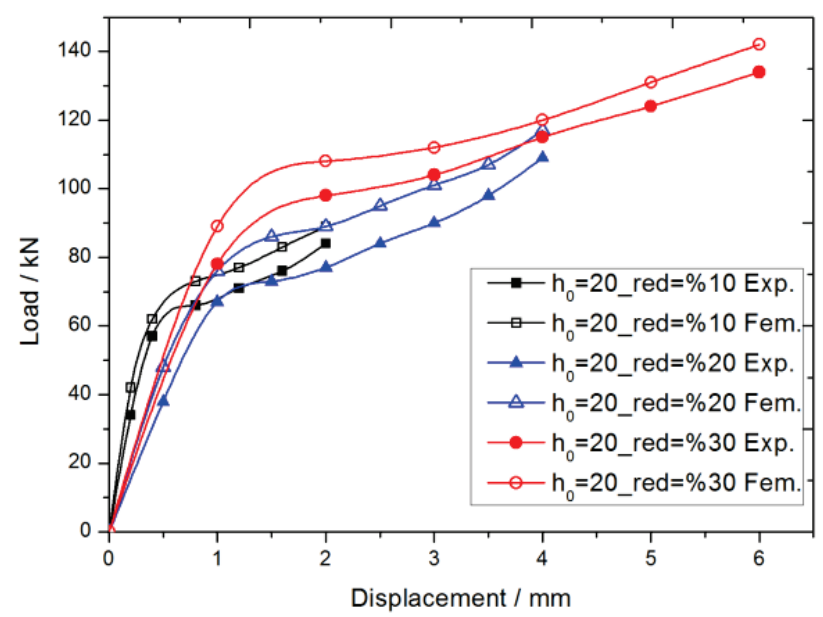

Figure 7 Comparison of experimental and FEM load-displacement curves for $20 \mathrm{~mm}$ 
Fig. 7 gives the load-displacement diagram for the 20 $\mathrm{mm}$. initial height and $10 \%$ reduction value both experimentally and theoretically. Forming load increases rapidly and from a certain point load value raises linearly and FEM and experimental forming load curves show good agreement.

At the beginning of loading material flows elastically. In the plastic region, the difference between experimental and FEM results is getting smaller with increasing displacement. When reduction increases $10 \%$, upsetting load increases $21 \%$ for both in experimental and FEM results. It can be also seen in Fig. 4 that forming load reaches about $120 \mathrm{kN}$ and FEM result is quite closer. Also comparison of experimental and FEM results for $30 \%$ reduction ratio in height is given in the same figure that the difference between FEM and experiments is about $10 \%$ for maximum upsetting load which is about $15 \mathrm{kN}$.

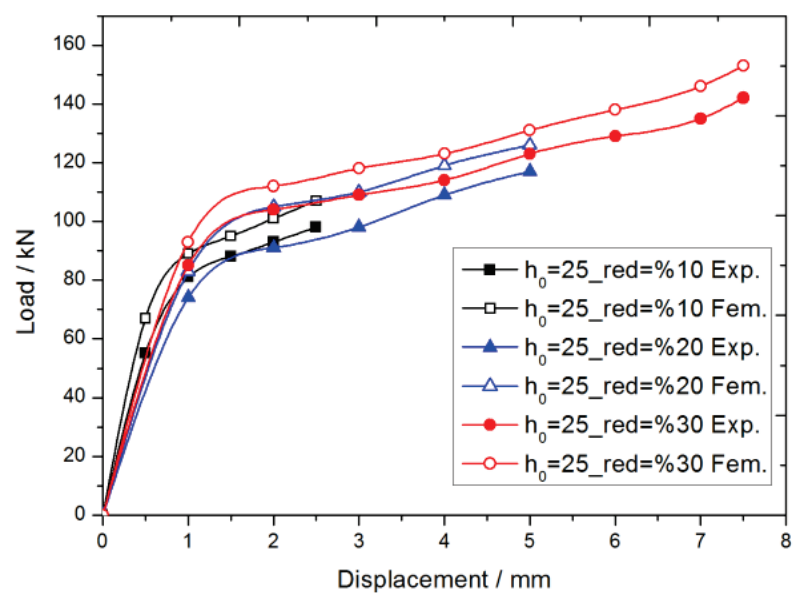

Figure 8 Comparison of experimental and FEM load-displacement curves for $25 \mathrm{~mm}$

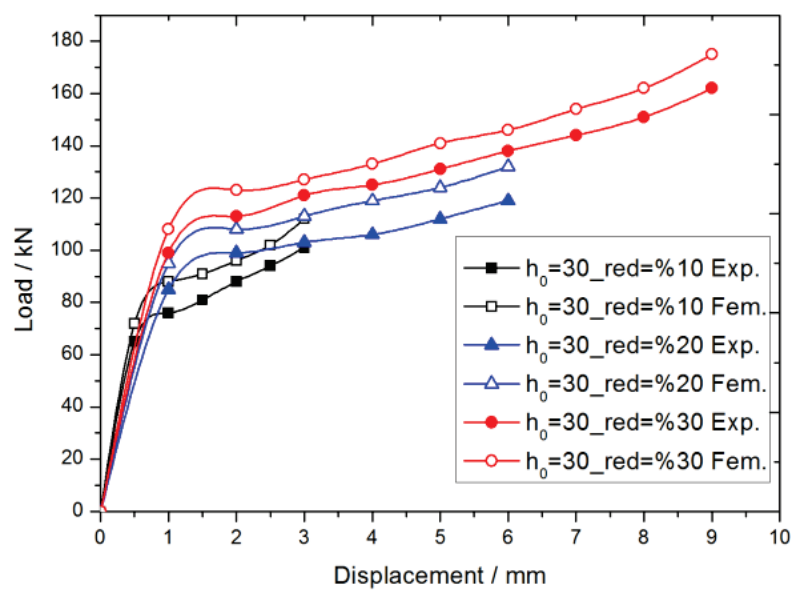

Figure 9 Comparison of experimental and FEM load-displacement curves for $30 \mathrm{~mm}$

The load-displacement curves for $10 \%, 20 \%$ and $30 \%$ reduction for $25 \mathrm{~mm}$ initial height samples are given in Fig. 8. The difference between predicted maximum upsetting load value and experimental load is about $6 \%$. It is seen that load-displacement curves are quite similar. At the beginning, the load increases rapidly both in experimental and FEM curve and at the forming stage slight difference occurs. It is clearly seen in the figure that curves are so close to each other most of the process and prediction load of upsetting of bimetallic hollow disc is $12 \mathrm{kN}$ higher than experimental load value.

Fig. 9 shows that maximum load difference for 30 $\mathrm{mm}$ initial height and $30 \%$ ratio is $8 \%$ and also it can be seen that the FEM based prediction curve is quite suitable with the experiments. In the given figures, FEM solutions and forming loads obtained from the experiments are compared. When diagrams are examined entirely, first height of the sample switches from $20 \mathrm{~mm}$ to $25 \mathrm{~mm}$. and the difference between FEM loads values for $10 \%$ reduction height changes in the rate of $12 \%$. The change between experimental load values is observed as $14 \%$. When a $13 \%$ increase is observed in FEM loads for 25 $\mathrm{mm}$ and $30 \mathrm{~mm}$. sample heights, change in the experimental loads is $11 \%$. While approximately $8 \%-9 \%$ load change is observed in initial height increase and FEM load values in the experimental results where reduction rate is $20 \%$ a change in the ratio of $7 \%$ in the experimental loads is observed.

While the difference is $10 \mathrm{kN}$ for $20 \mathrm{~mm}$ sample height between load values obtained by using DEFORM$3 \mathrm{D}$ software and experimental load values, when the reduction is $20 \%$ the difference is $13 \mathrm{kN}$ and the difference is an acceptable difference such as $14 \%$ for 30 $\%$ reduction. When the sample height is $25 \mathrm{~mm}$ for $10 \%$ reduction, the maximum load difference between experiment and FEM result is $30 \%$ and for $30 \%$ reduction the difference is $13 \mathrm{kN}$. While for $30 \mathrm{~mm}$ sample height there is $13 \mathrm{kN}$ difference at $10 \%$ reduction, for $30 \%$ reduction value where the highest deformation occurs a $15 \mathrm{kN}$ difference between FEM approach and experimental data is observed.

It can be seen from the figures that the FEM model shows close similarity to the experiments. In this respect, FEM model can be used to predict the forming load for different process parameters.

\subsection{ANN Analysis}

The ANN model was established, trained in MATLAB software and training procedure alters the weight of each neuron to a suitable prediction value. The ANN model gives adequate results comparing to the experimental results. In this study, the maximum absolute relative error for predicted values was recorded as $2.832 \%$. Hence, by using ANN values, satisfactory results could be obtained rather than the measured ones and therefore reduce time and cost of testing process. The best training algorithm for selected ANN among other training parameters is that with 1 hidden layer and 10 neurons. There is no strictly defined rule for designing the ANN structure. Nevertheless, neuron number in the hidden layers is crucial point to determine the complexity of the model.

Regression coefficient values $\left(R^{2}\right)$ of training, test and validation for the proposed ANN model is given in Fig. 10 and it can be concluded that the obtained regression coefficients of ANNs were highly good in both cases and it was decided that results would be accurate. The regression value of the test is 0.993 and moreover validity of the study is proved with the 0.99388 regression value. Training of the model was realized in MATLAB, using TRAINLM training function. TRAINLM updates weights 
and bias values in a back propagation algorithm according to Levenberg-Marquardt (LM) optimization. The LM method was applied repeatedly until the satisfactory training result was obtained and at the end the regression value reached 0.99033 . The forming load obtained by the ANN and experiments for the test data is compared in Fig. 11. It is observed that the predicted results are in good agreement with the experimental results. Hence, the trained model could be considered effective.
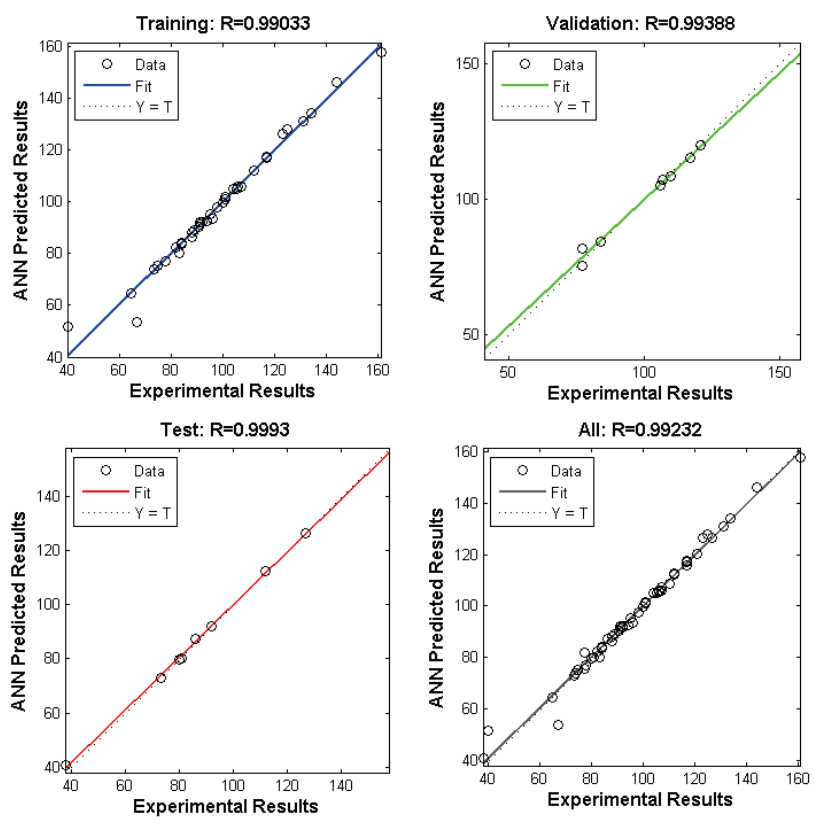

Figure 10 Regression values of the ANN model

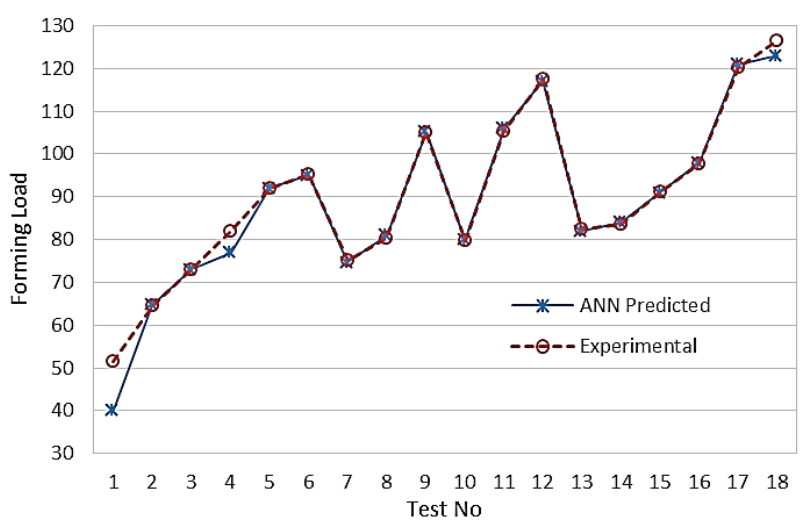

Figure 11 Experimental and ANN predicted load results in the test period

Fig. 12 shows the comparison of the experimental and calculated prediction results. It shows how well the variation in the output is defined by the target values. If this number was equal to one, that meant a perfect correlation between targets and outputs. The correlation coefficient was found to be 0.982 and very close to 1.0 value. It can be said that the proposed ANN model offers a great accuracy for bimetallic upsetting of hollow disc.

Percentage error values for the testing of the model are given in Fig. 13. and it can be seen that maximum error is $7 \%$ and most of the values are in the range of $(0.05-1) \%$. This error result values are very attractive for the success of the prediction and the proposed ANN model could be used for different friction factor, height / diameter ratio $(\mathrm{H} / \mathrm{D})$ and percentage reduction $(\%)$ parameters. The initial results for the ANN prediction were taken from the FEM model. The obtained ANN prediction results are given in Fig. 14.

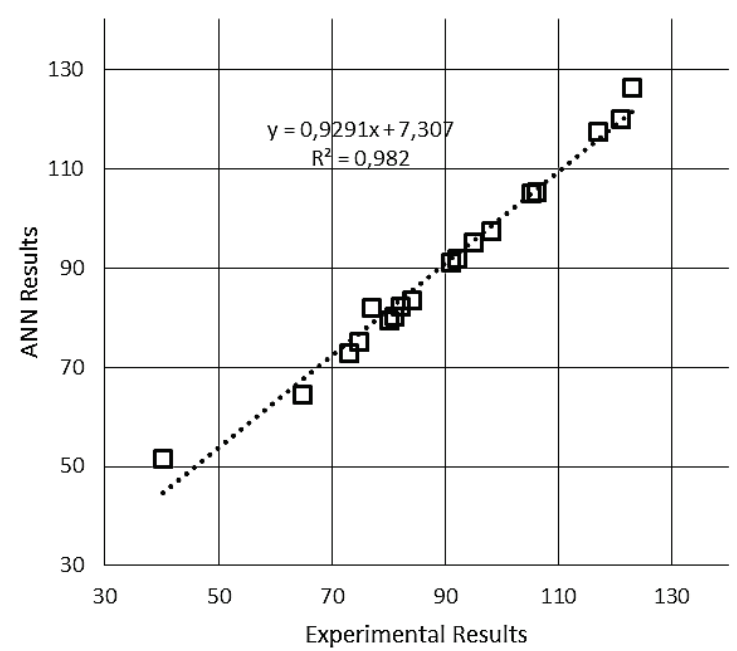

Figure 12 Comparison of experimental and ANN-predicted values for forming load

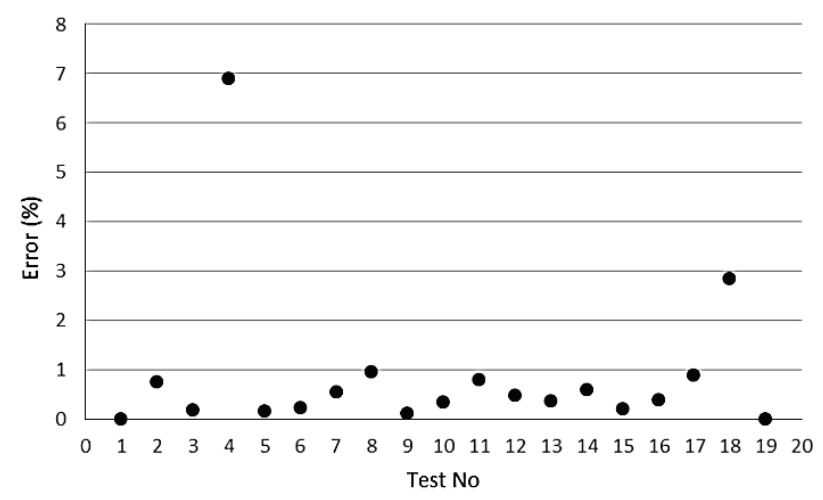

Figure 13 Percentage error of the network

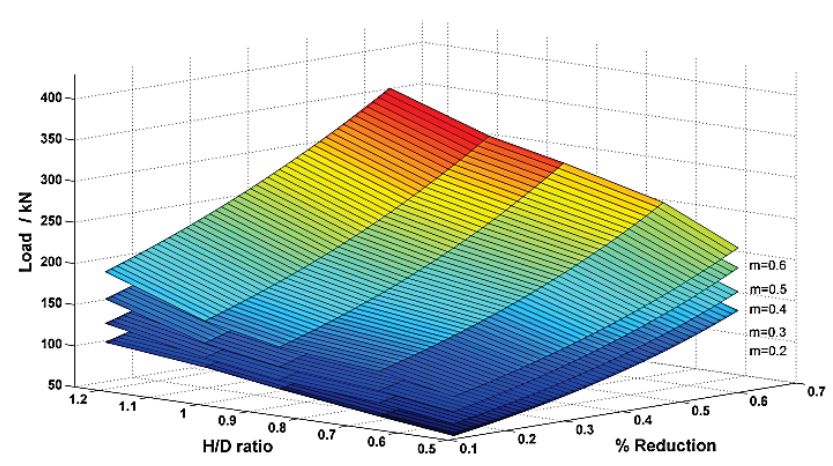

Figure 14 ANN load prediction results

ANN model was used to predict the forming load for expanded process parameters. Friction factors were implemented as $m=0.2,0.3,0.4,0.5,0.6$ and percentage reductions were selected as $0.1,0.11, \ldots, 0.49,0.50$ of the expanded ANN model. FEM results were used for initial values of ANN model because of its similarity to the experimental results. Effects of all process parameters on forming load are given in Fig. 14. It is seen from the figure that forming load increases exponentially when $H / D$ remains constant for all percentage reduction ratios. Higher reduction values cause higher effective stress hence forming load increases. For the same $H / D$ ratios, frictional conditions affect forming load and this leads to 
increase linearly about $20 \%$. The effect of friction is much more significant for higher $\mathrm{H} / \mathrm{D}$ ratios and also for higher reduction in height values. For 0.6 reduction value and $0.65 \mathrm{H} / \mathrm{D}$ ratio the forming load increases by about $23 \%$ for all frictional conditions. This point can be named as a critical forming limit. The forming load increases with the increasing H/D ratios linearly for the rest of the forming process for the same percentage reduction values.

\subsection{UB Analysis}

Upper Bound Method was established from proposed velocity field which satisfied the boundary conditions. The UB results were compared with experimental ones and they are given in Fig. 15-17.

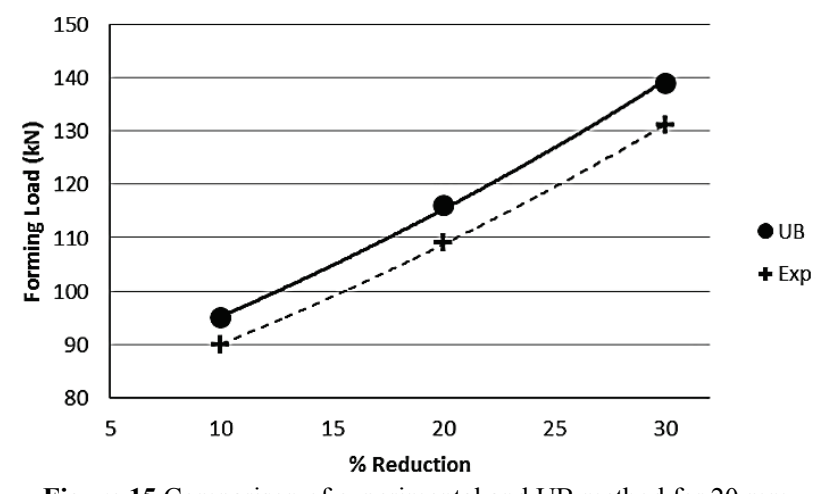

Figure 15 Comparison of experimental and UB method for $20 \mathrm{~mm}$ initial height $(H / D=0.65)$

Load comparison between UB method and experimental results for $H / D=0.65$ ratio is given in Fig. 15 . It is clearly seen that there is a linear change when reduction ratio reaches from $10 \%$ to $30 \%$. Load increases by about $60 \%$. In Fig. 16, the change of the forming load versus reduction in height was expressed. The load change showed an exponential character and the change is dominant with the increase of the $H / D$ ratio. The theoretical results are found to be higher than the experimental results. The calculated UB load is $3.7 \mathrm{kN}$ higher than the measured one.

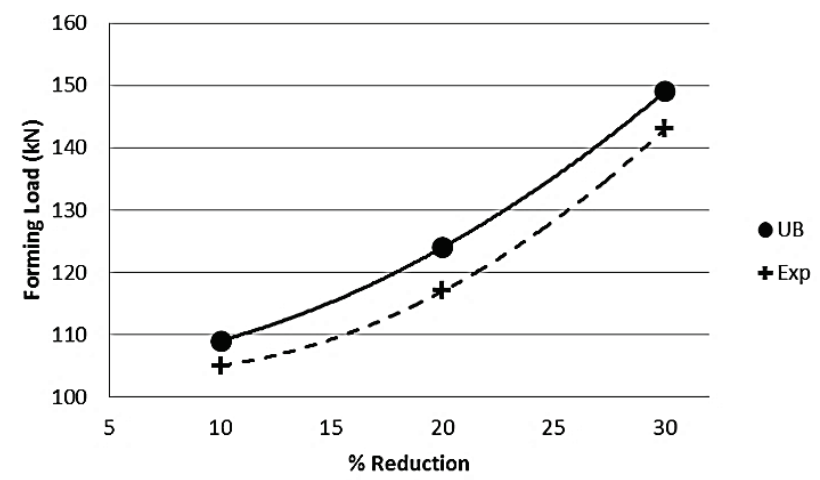

Figure 16 Comparison of experimental and UB method for $25 \mathrm{~mm}$ initial height $(H / D=0.85)$

It is seen from Fig. 17 that the theoretical predictions are higher than experimental results and also there can be seen a good agreement between the UB results and the experiments. The maximum difference is about $5.5 \%$ and this difference is a reasonable one.

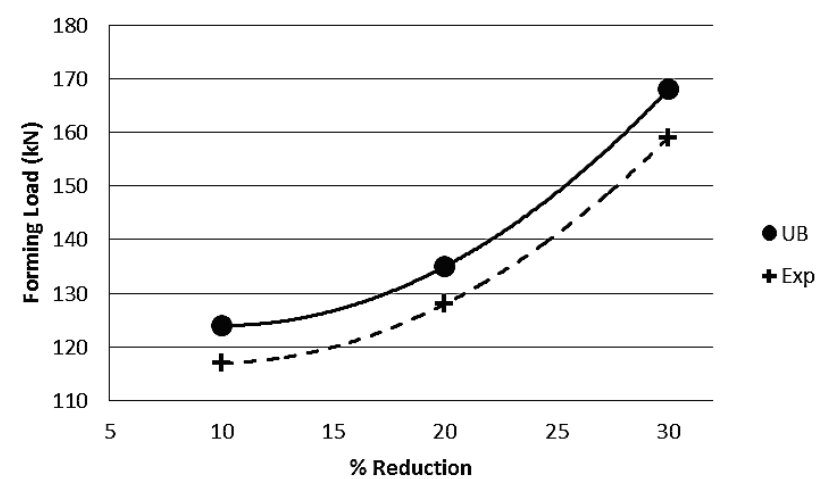

Figure 17 Comparison of experimental and UB method for $30 \mathrm{~mm}$ initial height $(H / D=1.00)$

If the results are concluded together it can be seen that the experimental loads were recorded smaller than UB results for all experimental setups. This accords with the main idea of UB method and gives perspective to estimate the forming load for upsetting of bimetallic material process.

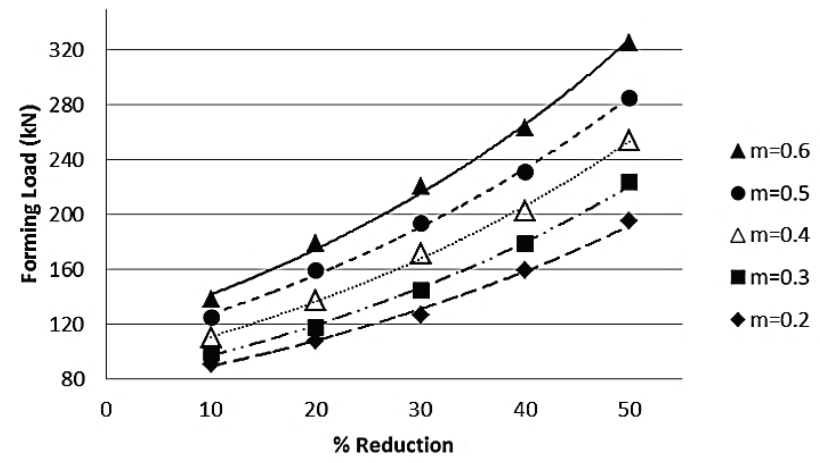

Figure 17 Upper Bound Method predictions for different friction factors $(H / D=1)$

The upper bound method was expanded to predict the forming load for various parameters. Fig. 18 shows a comparison of UB predicted forming load versus percentage reduction in height between different friction factors for $H / D=1$. The friction factor $(m)$ values were decided from 0.2 to 0.6 . The determined friction factor of the experiments was 0.4. Generally, the forming load value increases with increasing reductions at higher friction factor, whereas it decreases slightly with increasing reduction at lower friction factor.

\section{Conclusions}

The paper presents experimental and theoretical approaches to obtain the optimum forming load and suitable prediction method for the bimetallic ring upsetting process. The forming load in the upsetting process was investigated in the presented study. The copper was used as core material and aluminum was used for sleeve material. The three imperative input parameters used as initial parameters are named: Height to diameter ratio, forming percentage of specimens, displacement of the punch and where the output parameter is forming load. The following observations were obtained by regarding the experimental results and comparison with three mathematical methods analyses named Finite 
Element, Artificial Neural Network and Upper Bound Method:

- It can be observed on the load - displacement diagrams that experimental results and FEM load results show a rather similar change. Also it is observed that in terms of maximum forming load approximately a maximum $8 \%$ difference between experimental values and FEM results occurred in all upsetting conditions.

- For specimens of having different slenderness ratios $(H / D)$ such as $1.0,1.2$ and 1.5 , it can be noted that the shorter the specimen, the higher the influence of friction forces and forces arise from the resistance of deformation resultant from mutual interaction of stresses, which come from the action of adjacent compression plates, varying throughout the height of the specimen.

- A mathematical model was established by using Upper Bound method for upsetting of bimetallic discs with satisfying the incompressibility and velocity boundary conditions to simulate the plastic deformation of the process. A number of different velocity fields can be used for predictions on metal forming processes.

- UB predicted loads are found to be generally higher than experimental values. Therefore, it can be concluded that the proposed UB model provides a useful limit forming load estimations with a sufficient accuracy for bimetallic upsetting discs.

- Comparisons showed that there is a good correlation between the experimental and the developed ANN results. In the statistical model, $R^{2}$ value between the experimental and the ANN results was found to be 0.982; therefore, this result points out the great capability of the developed ANN model to be a useful method for prediction of the forming load for different initial parameters.

- When the obtained results for all estimation methods are evaluated together, it can be concluded that the ANN model provides very close prediction results comparing to other mathematical models. The ANN model in this study is very easy developed and so much more flexible for the prediction of new parameters of the experiments and also proposes less computation time. As a result, proposed ANN model is a well trained-useful tool to be used for predictions of bimetallic upsetting processes.

\section{References}

[1] Chitkara, N. R.; Aleem, A. Extrusion of axi-symmetric bimetallic tubes: some experiments using hollow billets and the application of a generalized slab method of analysis. // International Journal of Mechanical Sciences. 43, (2001), pp. 2857-2882. https://doi.org/10.1016/S0020-7403(01)00066-2

[2] Haghigat, H.; Asgari, G. R. A generalized spherical velocity field for bi-metallic tube extrusion through dies of any shape. // International Journal of Mechanical Sciences. 53, (2011), pp. 248-253. https://doi.org/10.1016/j.jimecsci.2011.01.005

[3] Kazanowski, P.; Epler, M. E.; Misiolek, W. Z. Bi-metal rod extrusion-process and product optimization. // Materials Science and Engineering A. 369, (2004), pp. 170-180. https://doi.org/10.1016/j.msea.2003.11.002
[4] Haghigat, H.; Mahdavi, M. M. Analysis and FEM simulation of extrusion process of bimetal tubes through rotating conical dies. // Trans. of Nonferrous Met. Soc. China. 23, (2013), pp. 3392-3393 https://doi.org/10.1016/S1003-6326(13)62879-4

[5] Wifi, A. S.; Abdel-Hamid, A.; El-Monayri. H.; El-Abbasi, N. Finite element determination of workability limits for disks and rings under different upsetting conditions. // Journal of Materials Processing Technology. 56, (1996), pp. 918-932. https://doi.org/10.1016/0924-0136(95)01904-9

[6] Plančak, M.; Car, A.; Vilotic, D.; Movrin, D.; Krsulja, M. Upsetting of Bimetallic Components in Closed Die. // Engineering Review. 31, 2(2011), pp. 105-109.

[7] Kačmarčik, I.; Plančak, M.; Vilotic, D.; Tolnai, M.; Movrin, D.; Ivanisevic, A. Numerical Analysis of Bimetallic extrusion of gear-like components. $/ /$ The $6^{\text {th }}$ PSUUNS International Conference on Engineering and Technology (ICET-2013) Novi Sad, 2013 May 15-17, 2013.

[8] Eivani, A. R.; Karimi Taheri, A. A new method for producing bimetallic rods. // Materials Letters. 61, (2007), pp. 4110-4113. https://doi.org/10.1016/j.matlet.2007.01.046

[9] Barata Marques, M. J. M.; Martins, P. A. F. A Study of bimetal coins by the finite element method. // Journal of Materials Processing Technology. 26, (1991), pp. 337-348. https://doi.org/10.1016/0924-0136(91)90068-P

[10] Plančak, M.; Kačmarčik, I.; Vilotic, D.; Krsulja, M. Compression of bimetallic components- analytical and experimental investigation. // Annals of Faculty Engineering Hunedoara - International Journal of Engineering. 2, (2012), pp. 157-160.

[11] Essa, K.; Kačmarčik, I.; Hartley, P.; Plančak, M.; Vilotic, D. Upsetting of bi-metallic ring billets. // Journal of Materials Processing Technology. 212, (2012), pp. 817824. https://doi.org/10.1016/j.jmatprotec.2011.11.005

[12] Çetintav, I. Farklı malzemeler kullanılarak üretilmiş bimetalik malzemelerin mekanik özelliklerinin incelenmesi. Master Thesis, Trakya University, Institute of Natural Sciences. (2014)

[13] Ko, D. C.; Kim, D. H. Methodology of preform design considering workability in metal forming by the artificial neural network and Taguchi method. // Journal of Materials Processing Technology. 80-81, (1998), pp. 487-492. https://doi.org/10.1016/S0924-0136(98)00152-6

[14] Gudur, P. P.; Dixit, U. S. A neural network-assisted finite element analysis of cold flat rolling. // Engineering Applications of Artificial Intelligence. 21, 1(2008), pp. 4352. https://doi.org/10.1016/j.engappai.2006.10.001

[15] Azari, A.; Poursina, M.; Poursina, D. Radial forging force prediction through MR, ANN, and ANFIS models. // Neural Computing \& Applications. 25, 3(2014), pp. 849858. https://doi.org/10.1007/s00521-014-1562-8

[16] Sanjari, M.; Karimi Taheri. A.; Mohavedi, M. R.; An optimization method for radial forging process using ANN and Taguchi method. // Int. J. Adv. Manuf. Technol. 40, (2009), pp. 776-784. https://doi.org/10.1007/s00170-008-1371-2

[17] Djavanroodi, F.; Pirgholi, A.; Derakhshani, E. FEM and ANN Analysis in Fine-Blanking Process. // Materials and Manufacturing Processes. 25, (2010), pp. 864-872. https://doi.org/10.1080/10426910903367444

[18] Chun, M. S.; Biglou, J.; Lenard, J. G.; Kim, J. G. Using neural networks to predict parameters in the hot working of aluminum alloys. // Journal of Materials Processing Technology. 86, (1999), pp. 245-251. https://doi.org/10.1016/S0924-0136(98)00318-5

[19] Kim, D. J.; Kim, B. M. Application of neural network and FEM for metal forming processes. // International Journal of Machine Tools \& Manufacture. 40, (2000), pp. 911-925. https://doi.org/10.1016/S0890-6955(99)00090-5 
[20] Kim, D. J.; Kim, B. M.; Choi, J. C. Determination of the initial billet geometry for a forged product using neural networks. // Journal of Materials Processing Technology, 72, (1997), pp. 86-93.

https://doi.org/10.1016/S0924-0136(97)00134-9

[21] Mohammadi Majd, H.; Poursina, M.; Shirazi, K. H. Determination of barrelling curve in upsetting process by artificial neural networks. // Proceedings of the $9^{\text {th }}$ WSEAS International Conference on Simulation, Modelling and Optimization, (2009), pp. 271-274.

[22] Poshal, G.; Ganesan, P. An analysis of formability of aluminium preforms using neural network. // Journal of Materials Processing Technology. 205, (2008), pp. 272282. https://doi.org/10.1016/j.jmatprotec.2007.11.107

[23] Yang, D. Y.; Choi, Y.; Kim, J. H. Analysis of upset forging of cylindrical billets considering the dissimilar frictional conditions at two flat die surfaces. // Int. J. Mach. Tool Manuf. 31, 3(1991), pp. 397-404 https://doi.org/10.1016/0890-6955(91)90084-G

[24] Altınbalık, T.; Çan, Y. An upper bound analysis and determination of the barrelling profile in upsetting. // Indian Journal of Engineering \& Materials Sciences. 18, (2011), pp. 416-424.

[25] Hsu, H. H. A study on precision forging of spur gear forms and spline by the upper bound method. // International Journal of Mechanical Sciences. 44, (2002), pp. 1543-1558. https://doi.org/10.1016/S0020-7403(02)00067-X

[26] Martin, F.; Sevilla, L.; Camacho, A.; Sebastian, M. A., Upper bound solutions of ring compression test. // Procedia Engineering. 63, (2013), pp. 413-420. https://doi.org/10.1016/j.proeng.2013.08.211

[27] Chandra, A.; Srivastava, R. A Boundry element analysis of axisymmetric upsetting. // Math. Comput. Modelling. 15, 35(1991), pp. 81-92.

[28] Yeh, W. C., Wu, M. C., A variational upper-bound method for analysis of upset forging of rings. // Journal of Materials Processing Technology. 170, (2005), pp. 392-402. https://doi.org/10.1016/j.jmatprotec.2005.06.007

[29] Moncada, A.; Martin, F.; Sevilla, L.; Camacho, A. M.; Sebastian, M.A. Analysis of Ring Compression Test by Upper Bound Theorem as special case of non-symmetric part. // Procedia Engineering.132, (2015), pp. 334-341.

https://doi.org/10.1016/j.proeng.2015.12.503

\section{Authors' addresses}

\section{Önder Ayer, Ph.D.}

Trakya Universitesi, Mühendislik Fakültesi, Makina Mühendisliği Bölümü Merkez, Edirne, Turkey E-mail: onderayer@trakya.edu.tr 